\title{
Fenntarthatóság és klímaadaptáció a városfejlesztésben - lock-in elemzés Budapest XVII. kerületének példáján
}

\section{Sustainability and climate adaptation in urban development - lock-in analysis in Budapest XVII. district}

\author{
BUZÁSI ATTILA, CSIZOVSZKY ANNA
}

BUZÁSI Attila: egyetemi adjunktus, Budapesti Műszaki és Gazdaságtudományi Egyetem, Környezetgazdaságtan Tanszék; 1117 Budapest, Magyar tudósok krt. 2.; buzasi.attila@gtk.bme.hu; https://orcid.org/0000-0002-4088-9276

CSIZOVSZKY Anna: hallgató, Budapesti Műszaki és Gazdaságtudományi Egyetem, Környezetgazdaságtan Tanszék; 1117 Budapest, Magyar tudósok krt. 2.; cs.anna46@gmail.com; https://orcid.org/0000-0001-8341-4863

KULCSSZAVAK: klímaadaptáció; fenntarthatóság; városfejlesztés; lock-in

ABSZTRAKT: A klímaváltozás hatásai jelentősen befolyásolják a törekvést a fenntarthatóság irányába. A városkutatási témák között az utóbbi években a fenntartható fejlődés fogalma és célrendszere mellett előtérbe került a klímaadaptáció, azaz a klímaváltozáshoz való alkalmazkodás kérdésköre is. A szakpolitikai és tudományos relevancia ellenére a két fogalom viszonya, egymásra gyakorolt hatása - különösen gyakorlati szinten - nem tisztázott és kevésbé kutatott kérdés, az egymással szoros összefüggésben álló fogalmak párhuzamos vizsgálatát kevesen kísérelték meg. A sokasodó extrém időjárási jelenségeket kiváltó okok és a megoldandó problémák - aktív gazdasági tevékenységeik, népsűrűségük, valamint a kapcsolódó környezeti kihívások okán - a városokban koncentrálódnak. A városok tehát a megváltozott éghajlati viszonyokhoz történő alkalmazkodás kritikus tényezői.

A tanulmány célja, hogy Budapest XVII. kerületének példáján keresztül feltárja a városi fenntarthatóság, valamint a klímaadaptációs kritériumok egymásra gyakorolt hatását, és meghatározza lehetséges szinergiáikat. A rendelkezésre álló városfejlesztési beavatkozások komplex fenntarthatósági és adaptációs szempontú elemzése rávilágít azokra a tevékenységekre, melyek hosszú távon akár negatív hatásokkal is járhatnak, és ezáltal növelik az ún. lock-in jelenségek, vagyis a kényszerpályák kialakulásának veszélyét. Az elemzés során olyan értékelési keretrendszert alkalmaztunk, melynek segítségével a két terület közvetlen és közvetett hatásainak elemzése egyaránt lehetővé válik.

Habár a vizsgálat egy konkrét kerület példáján keresztül valósul meg, az értékelési keretrendszer bármely településre szabadon átalakítható, ezáltal ex-ante végezhető el a tervezett városfejlesztési beavatkozások komplex hatásértékelése. A tanulmány tehát nemzetközi szinten is kevésbé kutatott, gyakorlati szempontból azonban kiemelt jelentőséggel bíró területre fókuszál, valamint szélesíti a hazai városkutatás szakirodalmi bázisát.

Attila BUZÁsI: assistant professor, Department of Environmental Economics, Budapest University of Technology and Economics; Magyar tudósok krt. 2., H-1117 Budapest, Hungary; buzasi.attila@gtk.bme.hu; https://orcid.org/0000-0002-4088-9276

Anna CSIZOVSZKY: student, Department of Environmental Economics, Budapest University of Technology and Economics; Magyar tudósok krt. 2., H-1117 Budapest, Hungary; cs.anna46@gmail.com; https://orcid.org/0000-0001-8341-4863 
KEYWORDS: climate adaptation; sustainability; urban development; lock-in

ABSTRACT: Due to global warming, humanity has to face irreversible effects regarding social, environmental, and economic systems. Climate change and its impacts fundamentally affect the transition to sustainable development. Therefore beside sustainability, resilience is getting more and more popular in urban research. Despite the academic relevance, it is barely understood how these paradigms affect each other, particularly in practice. People, economic functions and related environmental encumbrances are densified in cities that are main contributors of global warming and related extreme weather events. Thus, urban areas play a crucial role in the adaptation to changing conditions.

This study attempts to identify how the core spatial planning actions limit sustainability and resilience at the micro-level. The study area is the 17th District of Budapest, the capital of Hungary, but the used method can be adapted to other settlements based on local circumstances. Aspects of strong sustainability, adaptation to climate change, and lock-in are taken into account in three different but associated ex-ante surveys. Direct and indirect effects are deeply considered in the presented framework as part of a complex impact assessment. The elaborated method eases the identification of trade-offs, synergies, and potential lock-ins among the key projects at the design stage; hence it can be a beneficial ex-ante tool for decision-makers. The presented analysis can be used universally; however, the results depend significantly on local conditions, purposes, and the defined adaptation aspects.

The applied methodology provides decision-making in urban development with a novel input, which was not or barely considered before, despite the fact that adaptation to climate change as a horizontal part of sustainable development is crucial. It is shown that these aspects can stay hidden in a comprehensive sustainability assessment. The identified adverse effects should not automatically mean the cancellation of the project. On the contrary, they can open decision-makers' and planners' eyes to potential issues, which risk long-term transition to sustainability. Besides, they indicate where more conscious and profound planning and implementing is required.

In sum, the elaborated method is capable of a complex ex-ante impact assessment of urban planning projects. It can unveil previously hidden aspects of sustainability and potential path dependencies thus, it can be a useful tool for decision-makers and urban planners.

After a short introduction, an academic review sums up linkages between the paradigms of sustainability and resilience. Then the description of the study area and methods are discussed, followed by the analysis of results, including synergies and trade-offs of the three ex-ante cases. Finally, the potentials, limits, and challenges of the elaborated impact assessments are featured in the conclusion with recommendations for further research paths.

\section{Bevezetés}

A városok kiemelt szerepe a fenntartható fejlődés megvalósításában - a bennük koncentrálódó népesség, gazdasági tevékenységek, illetve az ezekhez kötődő környezeti terhelések és megoldandó problémák révén - vitathatatlan (Battersby 2017; Cohen 2017; UN 2019). A városi fenntarthatóság analitikus értékeléséről az utóbbi években a vizsgálati fókusz egyre inkább a városfejlesztési összefüggések gyakorlatorientált feltárására helyeződött, ami megnyitotta az utat az erősen interdiszciplináris jellegű tanulmányok előtt. E kutatási pályán halad a 2000-es évek eleje óta egyre hangsúlyosabbá váló adaptáció kérdésköre is, mely - az eredetét jelentő műszaki és ökológiai tudományok látóköréből kikerülve - a város- 
kutatás egyik legnépszerűbb témakörévé nőtte ki magát. A klímaváltozással összefüggő alkalmazkodási kihívások kutatása - a városok dinamikus jellege, valamint a továbbra is élesen fennálló fenntarthatósági kérdések mellett - olyan szakterületté vált, amely önállóan is megállja helyét a különböző tudományágak egymást átfedő rétegeiben.

A magyar nyelvű szakirodalomban is szép számmal találunk a városi fenntarthatóságot különböző területekről értékelő tanulmányokat, melyek - a teljesség igénye nélkül - a zajszennyezés (Baros 2012), a közlekedés (Csiszár et al. 2019; Fleischer 2019; Zefreh, Török 2020), a zöldfelületek (Kántor et al. 2017; Szabó et al. 2016), a települési környezetvédelem jogi összefüggései (Fodor et al. 2016), vagy éppen a kapcsolódó városértelmezések, például a kreatív és okos város (Baji 2017; Egedy 2017; Kun 2016; Lados, Tóth 2019) területén születtek. A Kárpát-medencére vonatkozó regionális klímamodellek (Kis et al. 2017; Pongrácz et al. 2014; Torma 2019) szerint a nyári hőhullámok, valamint a megváltozó csapadékviszonyok alapvetően befolyásolják a városok jelen- és jövőbeli éghajlati sérülékenységét. A nemzetközi szakirodalomban tapasztalt fokozott érdeklődés a magyar nyelvű kutatásokat is ösztönözte a klímaadaptáció területén. Az éghajlati sérülékenység térbeli jellemzése (Farkas et al. 2015; Uzzoli, Bán 2018) mellett a városokat és városfejlesztési folyamatokat érintő tanulmányok (Csete, Buzási 2016; Kohán et al. 2011) egyaránt megtalálhatók a hazai szakirodalomban. Megfigyelhető azonban, hogy a fenntarthatóság és a klímaadaptáció területe mindeddig nem, vagy csak igen kis mértékben kapcsolódott össze az elvégzett kutatásokban.

Az itt röviden bemutatott tudományos hátteret figyelembe véve kijelentheto", hogy elengedhetetlen a klímaközpontú városfejlesztés integrálása a gyakorlatba, amely egyszerre jelenti az üvegházhatású gázok kibocsátásának csökkentését, valamint a megváltozó klimatikus viszonyokhoz való hatékonyabb alkalmazkodás hangsúlyosabbá válását. Mivel a városi fenntarthatóság és a klímaadaptáció egymással szorosan összefüggo", ám a megoldásokat és a szükséges beavatkozásokat tekintve sokszor markánsan szembenálló fogalmakat takar, azok integrációja elengedhetetlen a modern városfejlesztésben.

Tanulmányunk célja a városi fenntarthatóság és klímaadaptáció szempontjainak integrálása olyan értékelési keretrendszer segítségével, melynek használata hozzájárul a városfejlesztési beavatkozások komplex elemzéséhez. A kidolgozott módszertan illeszkedik a nemzetközi szakirodalomban egyre hangsúlyosabban felbukkanó ún. lock-in elemzésekhez, mely fogalom alatt a hosszú távú beágyazódások, negatív következmények feltárását és - ex-ante értékelés esetén - megelőzését értjük. Az elemzés Budapest XVII. kerületére fókuszál. Ez nagy népességszámú, heterogén területhasználattal bíró városrész, ahol az önkormányzat nem rendelkezik a klímaváltozás negatív hatásaira válaszul beavatkozásokat tartalmazó stratégiával. A kerület fejlesztési irányait megszabó integrált településfejlesztési stratégia (ITS) célrendszerének és városfejlesztési beavatkozásainak lock-in szempontú elemzése egy olyan interdiszciplináris terü- 
leten járul hozzá a hazai szakirodalmi bázis szélesítéséhez, melyet nemzetközi szinten egyre gyorsuló ütemben növekvő publikációs aktivitás jellemez.

A következő fejezetekben bemutatjuk a városi fenntarthatóság és a klímaadaptáció elméleteinek kapcsolódási pontjait, majd a vizsgált terület és a módszertan ismertetése után az értékelési keretrendszer által definiált pozitív és negatív szinergiák feltárására kerül sor. Az eredmények bemutatását a kidolgozott módszertan korlátait és lehetőségeit felvonultató diszkusszió, valamint a jövőbeli kutatási irányokat is felvázoló összefoglalás követi. A tanulmány célja olyan értelmezési keretrendszer felállítása, melynek segítségével a városfejlesztési döntések meghozatala előtt - vagyis ex-ante módon - nyílik lehetőség a lehetséges kényszerpályák feltérképezésére. Az esettanulmányként kiválasztott XVII. kerület később bemutatandó társadalmi, gazdasági és környezeti heterogenitása révén megfelelő terepet nyújt az új módszertan tesztelésére, egyszersmind megadja a lehetőséget az alkalmazhatósági kör szélesítésére, más települések sajátos viszonyainak figyelembevételére is.

\section{Városi fenntarthatóság és klímaadaptáció}

Kijelenthető, hogy a fenntartható fejlődés fogalma Európa-szerte integrálódott a várostervezési gyakorlatba (González Medina, Fedeli 2015), miközben a hangsúly az akadémiai értelmezésekről a mérhetőségre (Anderies et al. 2013; Bozza et al. 2015) helyeződött. A fenntarthatóság helyi viszonyokon és jellegzetességeken - erőforrásokon, lehetőségeken, célokon, urbanizációs folyamatokon (Enyedi 2011), stb. - alapuló erőforrás-gazdálkodási kérdésként értelmezhető a generációkon átívelő társadalmi jólét szolgálatában (Buzási, Szalmáné Csete 2018), miközben elérésének egyik kulcsa a helyi kezdeményezéseken alapuló fenntartható projektek megvalósítása (Szlávik 2014).

Válaszként az erőforrások túlzott kiaknázása által okozott károkra (Champagne, Aktas 2016), amelyek a Föld éghajlatának megváltozását, történelmi éghajlati adatoktól való eltérését okozzák (Lizarralde et al. 2015), akadémiai körökben és a gyakorlatban egyaránt egyre nagyobb szerepet kap az ellenálló képesség fogalma (Roostaie et al. 2019). Az ellenálló képességet napjainkban leginkább a klímaváltozás által kiváltott kockázatok (rövid és hosszú távú hatások, katasztrófák vagy szélsőséges események) kezelésének tekintik (Carter et al. 2015; Engle et al. 2014). A korábbi akadémiai nézetek mérnöki megközelítést alkalmaztak (Folke 2016), vagyis a rendszer állapotának változatlanságát hangsúlyozták a zavarások ellenében (Friedland, Gall 2012). Ezt a megközelítést egészíti ki az alkalmazkodóképesség rugalmasságot, változást és progresszivitást előtérbe helyező, egyre népszerűbb fogalma (Buzási, Szalmáné Csete 2018; Lew et al. 2016; Roostaie et al. 2019), hiszen a városok dinamikus jellege megköveteli a folytonos átalakulás, változás lehetőségének integrálását (Engle et al. 2014). Jelen tanulmányban szinoni- 
maként használjuk a reziliencia és a rugalmas alkalmazkodóképesség fogalmát, mivel a korábban ismertetett, ellenálló képességet hangsúlyozó értelmezés alkalmazhatósága a dinamikusan változó városi viszonyok között erősen korlátozott.

Számos tanulmány mutat rá a fogalmak zavaros kapcsolatára, mellyel párhuzamosan hiányzik a gyakorlati alkalmazásukhoz elengedhetetlen, egységes értelmezési keretrendszer is (Bocchini et al. 2014; Lew et al. 2016; Marjaba, Chidiac 2016; Phillips et al. 2017; Roostaie et al. 2019; Xu et al. 2015). Roostaie és szerzőtársai (2019) hangsúlyozzák, hogy mindkét fogalom többdimenziós: az egyes tudományágak külön-külön kezelik különféle szempontjaikat, s így a két paradigmát összehasonlító tanulmányok eltérő összefüggéseket tárnak fel a vizsgált területnek és a vizsgálat mélységének megfelelően.

A fenntartható fejlődés megkívánja a rugalmasan alkalmazkodó ökoszisztémákat, valamint társadalmi és gazdasági rendszereket, melyek rezilienciájának hiánya könnyen nem fenntartható állapotot idézhet elő (Folke et al. 2002). A kétirányú kapcsolatok összetettségét bizonyítja, hogy az ökológiai alkalmazkodóképesség javítja a gazdasági fenntarthatóságot, azonban ez a kapcsolat fordítva ritkán mondható el (Xu et al. 2015). A klímaadaptáció a víziók és a gyakorlat összekapcsolásával hozzájárul a fenntartható fejlődéshez, a külső hatásokra reagálás révén elősegíti a fenntarthatóság jobb megértését, azonban nem elégséges annak leváltására (Buzási, Szalmáné Csete 2018). A klímaadaptáció és a fenntarthatóság kapcsolatát vizsgálva több tanulmány is arra a megállapításra jutott, hogy az itt vázolt kapcsolatrendszer okán szükséges a rugalmas alkalmazkodási képességként értelmezett reziliencia beépítése a fenntarthatóság értelmezési keretrendszerébe (Roostaie et al. 2019). Az integráció megköveteli az alkalmazkodóképesség hosszú távú perspektíváját és a kívánt állapot(ok) meghatározását (Xu et al. 2015), azonban a fogalmak közös platformon történő kezelése során konfliktusok is felmerülhetnek: egy ellenálló képességre fókuszáló stratégia hatékonysága a teljes hatékonyság - és ennek következtében a fenntarthatóság - rovására is mehet (Chelleri et al. 2015). Sőt, megfordítva, sikeres fenntarthatósági kezdeményezések is hathatnak az alkalmazkodóképesség ellenében (Lew et al. 2016).

Míg a városok dinamikusan változnak, addig a változásokat befolyásolni igyekvő beavatkozásokat kényszerpályák korlátozhatják, melyek - többek között - a tervezési folyamatból, a technológiából, illetve a megvalósítás során felmerülő döntésekből, berögzült eljárási struktúrákból erednek. A beavatkozások lehetséges útjait és sikerességét tovább szűkítheti a normák, társadalmi és egyéni szokások, rutinok alkotta társadalmi tehetetlenség, de akár a gazdasági nyomás is. Amint az infrastruktúra, az alacsony sűrűségü városi forma, az intézményi és társadalmi gyakorlatok megszokottá, elfogadottá válnak, illetve nehezen változtathatók meg, berögződéseket, ún. lock-in jelenségeket hoznak létre (Romero-Lankao et al. 2018). A lock-in folyamat és a városi növekedés hosszú távú hatásai még kevéssé tisztázottak, az infrastruktúra kiépítése azonban folytatódik a városokban anélkül, hogy részletesen elemzésre kerülnének azok az összefüggések, melyek befolyásol- 
hatják a hosszú távú fenntarthatósági célok teljesülését, megvalósíthatóságát (Chester et al. 2014).

A mitigációs és adaptációs stratégiák megértésére, fejlesztésére és végrehajtására irányuló kísérletek jellemzően egymástól elszigetelten működnek, vagyis kevés erőfeszítés irányul a rendszerszintű következmények feltárására, pozitív szinergiák létrehozására vagy a negatív tovagyürűző hatások elkerülésére. Ez a megközelítés a klímaváltozás negatív hatásait ellensúlyozó városfejlesztési beavatkozások dominanciájának növekedésével és az egymásra hatás bonyolultságával párosul, ily módon nem várt kimenetelekhez vezet. Gyakran negatív hatások lépnek fel egy adott mitigációs vagy adaptációs intézkedés megvalósítását követően, melyek hosszú távon is meghatározzák egy város nem fenntartható működését (Ürge-Vorsatz et al. 2018). A várostervezésnek azonban lehetősége nyílik szinergiák kialakítására a beavatkozások gondos tervezésével, a közvetlen és közvetett hatások komplex értékelésével. A klímaadaptáció és a városi fenntarthatóság tehát egymást kiegészítő fogalmak, azonban értelmezésük - különösen a városfejlesztés gyakorlatában - még kiforratlan. Tanulmányunk célrendszere illeszkedik a feltárt tudományos hiátushoz, melynek megfelelően a városi fenntarthatósági és alkalmazkodási szempontok a lock-in értékeléssel logikailag összekapcsolódnak, ám mégis külön pontokként jelennek meg a következő fejezetekben.

\section{Vizsgált terület és alkalmazott módszertan}

A vizsgálat helyszíneként Budapest XVII. kerületére esett a választásunk. Ennek egyik legfőbb oka a kerületre jellemző változatos területhasználat, illetve a klímaváltozással szemben különösen sérülékeny társadalmi csoportok szignifikáns jelenléte. Bár a terület Budapest részét képezi, mégis sokban hasonlít az agglomerációs településekhez, miközben közel 90 ezres lakossága remekül beilleszthetővé teszi Magyarország nagyobb városainak sorába is. Az 1970-es években épített lakótelepek körül többé-kevésbé városias központ alakult ki, míg a külső területek képe kevéssé változott: megőrizték kertvárosias jellegüket és szellős beépítésüket. A kerület külső határán mezőgazdasági tevékenység folyik, a belvároshoz közelebbi részei pedig gazdaságilag jelentősebbek. Klasszikus barnamezős terület a volt Egyesült Vegyiművek helyén alakult ki, de számos felhagyott vagy alulhasznosított ingatlan (Hajdú-Bogáti villa, egykori mezőgazdasági termelőszövetkezetek raktárai, strandok) is található a kerületben, melyek megszűnő gazdasági tevékenységek után maradtak hátra, rendezetlen tulajdonviszonyokkal.

Rákosmente társadalmi mutatói (pl. iskolázottság, foglalkoztatottság) elmaradnak a fóvárosi értékektől, azonban az országos helyzetnél kedvezőbb képet festenek. Probléma a szabadidős lehetőségek korlátozottsága, a szakképző vagy felsőoktatási intézmény hiánya, valamint az egészségügyi ellátórendszer túlterheltsége. Habár a kerületrészek között társadalmi értelemben is szignifikáns kü- 
lönbségek tárhatók fel, az elemzés a kerület egészére koncentrál. Rákosmente esetében az országos átlagot meghaladó a 60+ évesek aránya, valamint az öregségi mutató. Ez az utóbbi évtized folyamatos emelkedésének köszönheto", melynek változatlansága mellett az időskorú lakosság létszáma 2050-ig 24000 főről 40000 före is nőhet. A klímaváltozás szempontjából legsérülékenyebb társadalmi csoportok egyike tehát napjainkban is meghatározó a kerület életében, és ez csak tovább erősödik a XXI. század közepéig.

Rákosmente területét sűrű egyéni és közösségi közlekedési úthálózat szövi át, mely közúti infrastruktúra a napi szintű nagy átmenő forgalom és ingázás terheivel küzd. A kerület életét a nemzetközi légi forgalom is érinti, hiszen a budapesti Liszt Ferenc Nemzetközi Repülötér egy része is a kerület határán belül található. Emellett számos zöldfelülettel, sőt természetvédelmi területtel is rendelkezik a kerület, következésképpen Rákosmente területhasználat szempontjából nagy változatosságot mutat. A területhasználat diverzitásán kívül vizsgálatunk során fontos szempont volt, hogy önálló klímastratégiával még nem rendelkező területet válasszunk, mely esetében ugyanakkor az egy szinttel feljebb elkészített fóvárosi dokumentum mégis megfelelő támpontokat tudott szolgáltatni az elemzéshez.

A tanulmányban célunk egy olyan értékelési rendszer kidolgozása volt, mely elsősorban a stratégia elemzésén nyugszik, és így segítségével a tervezett városfejlesztési beavatkozások ex-ante fenntarthatósági, klímaadaptációs és lock-in szempontú vizsgálata is megvalósítható. A célok elemzése során a közvetlen és közvetett hatások figyelembevétele kiemelt jelentőséggel bírt. Ennek megfelelöen, először a vizsgált terület helyzetének, problémáinak feltérképezésére került sor KSH (2020) és TeIR (2020) adatok, valamint a városfejlesztési dokumentumokat megalapozó vizsgálatok alapján (Budapest Főváros XVII. kerület Rákosmente Településfejlesztési Koncepciójának és Integrált Településfejlesztési Stratégiájának Megalapozó Vizsgálata, 2015). Ezt követően a XVII. kerületi területfejlesztési koncepció (Rákosmente Településfejlesztési Koncepciója 2015-2030, 2015) és integrált településfejlesztési stratégia (Rákosmente Integrált Településfejlesztési Stratégiája 2015-2020, 2015) kijelölt céljainak, a megvalósításukat szolgáló eszközöknek, valamint egyéb releváns kerületi és fővárosi stratégiák tanulmányozását végeztük el.

Végül, az integrált településfejlesztési stratégiában kijelölt kulcsprojektekre (1. táblázat) szűkítettük az értékelést, hiszen ezek a leginkább ambicionált városfejlesztési beavatkozások azok, melyek megvalósítását a városvezetés lényegi kérdésként kezeli a nagyobb léptékű, holisztikusabb célok elérése érdekében. Ex-ante megközelítésünk keretében szándékosan nem tértünk ki a tervezési idöszakban megvalósult projektekre, illetve a kulcsprojektekhez kapcsolódó számos beavatkozást sem értékeltük. Ennek oka, hogy a bemutatandó módszertant és az alkalmazásából származó eredményeket jellemzően a következő városfejlesztési tervezési időszakban tudják a döntéshozók használni. Az ún. „erős fenntarthatóság" és a proaktivitás elvét figyelembe véve, az ex-ante értékelés kecsegtet olyan 
1. táblázat: A stratégiai célok és a kulcsprojektek rendszere List of strategic goals and key urban development projects

Stratégiai cél Kulcsprojekt
Energetikai megújítás és egészséges
1. Középületek energetikai megújítása
környezet kialakítása
2) Megújuló erőforrások használatának elősegítése
Közszolgáltatások minőségének és
1) Szakorvosi rendelő bővítése, korszerűsítése
elérhetőségének fejlesztése
2) Multifunkciós sportcsarnok fejlesztése
Identitás erősítése, közösségépítés,
1) Rákosmenti identitást erősítő projektek megvalósítása
közbiztonság növelése
2) Biztonságos közterek kialakítása
Rákosmente közlekedési
1) Úthálózat fejlesztések
hálózatának fejlesztése
2) Kerékpárforgalmi hálózat fejlesztése
Települési infrastruktúra fejlesztése
1) Városrészi alközpontok fejlesztése
Gazdaságfejlesztés
1) Munkahelyteremtés, szárazhegyi munkahelyi övezet kialakítása

Forrás: Rákosmente Integrált Településfejlesztési Stratégiája 2015-2020 (2015)

eredményekkel, melyek nyomán a lock-in típusú anomáliák és a kapcsolódó nem fenntartható folyamatok már eleve kikerülhetnek a megvalósítani szándékozott városfejlesztési beavatkozások közül. A módszertan alkalmazása jelen stádiumában tartalmaz még koncepcionális és gyakorlati korlátokat, ezek ismertetésére azonban nem itt, hanem az eredmények bemutatását célzó fejezetben teszünk kísérletet.

A kulcsprojektek komplex értékelése és hatásvizsgálata Ürge-Vorsatz és szerzőtársai (2018) logikáján alapszik. Ennek értelmében adott városfejlesztési eszközöket megválasztott alkalmazkodási vagy éppen mitigációs hatásértékelési szempontok szerint értékelünk, miközben a közvetlen és közvetett hatásaikat egyaránt figyelembe vesszük. Az alkalmazott módszer erénye, hogy használatával könnyen beazonosíthatók a tervezett intézkedések előnyei és veszélyei, valamint összevethetők a városfejlesztési beavatkozások során kialakuló negatív hatások, a fenntarthatóság és alkalmazkodás terén esetleg fellépő ellentétes érdekek. Emellett az értékelési rendszer alkalmazása megkönnyíti a szinergiák azonosítását, és kibővíti azok tervezési lehetőségeit.

A kulcsprojektek fenntarthatósági vizsgálata során a dimenziók meghatározásánál a Nemzeti Fenntartható Fejlődés Keretstratégia (2013) szempontjait tekintettük mérvadónak. A beavatkozások remélt közvetlen és közvetett eredményeit emberi, gazdasági, természeti és társadalmi erőforrások szerint értékeltük. Az értékelés során figyelembe vettük, hogy a kulcsprojektek megvalósítása során mennyire érvényesülnek a fenntartható fejlődés „erős fenntarthatóság” koncepciójának (Málovics, Bajmócy 2009), valamint a Nemzeti Fenntartható Fejlödés Keretstratégia szempontrendszerének megfelelő alapelvei.

Az integrált településfejlesztési stratégiában kijelölt kulcsprojekteket klímaadaptációs szempontból vizsgáltuk, mely esetben a fővárosi klímastratégiában 
megfogalmazott adaptációs célok tekinthetők az értékelési keretrendszer független változóinak. A dokumentum négy átfogó (zöldfelületi rendszer fejlesztése; hőszigethatás mérséklése az épített környezetben; árvízvédelmi rendszer fejlesztése, víztakarékosság, villámárvizek elleni védekezés; szélsőséges időjárási eseményekre, éghajlatváltozás egészségügyi hatásaira való felkészülés) és két tematikus (természeti és táji értékek, valamint az épített értékek, turisztikai desztinációk sérülékenységének csökkentése) adaptációs célt jelölt ki (Budapest Klímastratégiája, 2018). Az árvízvédelmi rendszer fejlesztéséről, víztakarékosságról, villámárvizek elleni védekezésről szóló célkitűzést két részre bontottuk, vízgazdálkodás és árvízvédelmi rendszer szempontok szerint, ahol előbbi a víztakarékosság, vízellátás témakörét, utóbbi pedig az árvizekre, villámárvizekre történő felkészülést foglalja magában. Ezt azért tettük, mert például a közintézmények energetikai korszerüsítése járhat hatékonyabb vízhasználattal, ugyanakkor árvízvédelmi szempontból kevéssé javítja a település helyzetét.

A kulcsprojektek fenntarthatósági és alkalmazkodási szempontú hatásvizsgálatán kívül - szintén Ürge-Vorsatz és szerzőtársai (2018) módszerét alapul véve, és a vizsgált területhez igazítva - lock-in elemzést is végeztünk. Ebben a tervezett intézkedéseket intézményi, infrastrukturális és viselkedési szempontból vizsgáltuk. Figyelembe vettük az intézkedéseket hátráltató, már meglévő kényszerpályákon, berögződéseken túl azon lehetőségeket is, melyek potenciálisan kialakulhatnak a beavatkozások eredményeként. Mindhárom elemzésben helyi fókuszt alkalmaztunk: ennek értelmében például a középületek energetikai korszerüsítése a fenntarthatóság gazdasági dimenziójában pozitívan hat, amennyiben a helyi foglalkoztatáshoz járul hozzá. Mindhárom értékelési rendszer esetén az eredmények jobb láthatósága érdekében - és a folyóirat formai követelményeit is figyelembe véve - ötfokozatú skálát vezettünk be. Ennek alapján „,+” jelölés az egyértelműen, közvetlen módon azonosítható pozitív hatást jelenti, míg „,” jelölés esetén gyengén, vagy közvetett módon teljesül az adott értékelési szempont. „NR" kóddal az adott szempontból nem releváns kulcsprojektek szerepelnek. A hatások kvalitatív leírásakor a közvetett vagy gyengén negatív, illetve közvetlenül és erősen negatív hatások egy, illetve két negatív jelölést kaptak.

\section{Eredmények}

Az alábbiakban a XVII. kerületi integrált településfejlesztési stratégiában meghatározott kulcsprojektek, azaz a kerület fejlesztési szempontból legrelevánsabb beavatkozásainak fenntarthatósági, klímaadaptációs és lock-in szempontú értékelésének eredményei olvashatók. Mivel a 314/2012. (XI.8.) Korm. rendelet alapvetően fenntarthatósági szempontú tervezési módszert ír elő az integrált településfejlesztési stratégiákra, a 2. táblázatban megjelenő értékekben jellemzően erősen pozitív jelölések köszönnek vissza. A fenntarthatósági dimenziókat szigo- 
rú rendben követő megalapozó tanulmány nagyszerü alapot szolgáltat a fenntarthatósági elvek projektszintü érvényre juttatásának is, ami a vonatkozó kormányrendelet egyik legnagyobb erőssége.

A középületeket célzó energetikai felújítások természeti erőforrások terén tapasztalható környezeti haszna a csökkenő energiafelhasználáson keresztül könnyen, közvetlen módon is megragadható. Az emberi és társadalmi pozitív hatások azonban már inkább közvetett úton jelentkeznek: előbbi esetben az esztétikusabb környezet és jobb fizikai körülmények kialakítása révén, utóbbi esetben pedig a közszolgáltatások minőségének fejlesztése útján. A gazdasági dimenzióban ugyanakkor pozitív és negatív hatás is feltételezhető egyszerre: ennek tisztázása csak a projekt végrehajtása során lehetséges, mivel a helyi gazdasági fenntarthatóság nagyban függ a helyi vállalkozók bevételeinek alakulásától. Jelen esetben tehát, ha a középületek energetikai megújításakor helyi vállalkozók végzik a tervezést és kivitelezést, az egyértelműen erősíti a helyi gazdaságot, azonban külső szereplők bevonásakor a tervezői / kivitelezői haszon más területi egységekhez köthető vállalkozásoknál hasznosul. Ez a szemléletmód Budapest kerületei esetében talán némileg sarkított, azonban a módszertan - a helyi jellegzetességeket figyelembe véve - lényegében bármelyik településre érvényesen alkalmazható, ahol a helyi gazdaságfejlesztés hangsúlyosabban jelenik meg. A továbbiakban eltekintünk az egyértelműen és könnyen beazonosítható pozitív hatások ismertetésétől, ehelyett a negatív sarokpontok feltárására helyezzük a hangsúlyt, ezzel is bemutatva a módszertan ex-ante várostervezési előnyeit.

Az értékelő mátrix jelölésrendszere alapján három kulcsprojekt esetében azonosítható be erős, közvetlen negatív hatás a természeti erőforrások terén. A multifunkciós sportcsarnok megvalósítása, annak fenntartása és üzemeltetése megnöveli a burkolt felületek arányát, kapcsolódó fejlesztései a Néppark zöldfelületét csökkenthetik, valamint az üzemeltetési periódusban tartós többlet erőforrás-felhasználás várható. Kiemelendő, hogy természetesen a megvalósított projekt esetében ezeknek a hatásoknak a legtöbbje csillapítható, azonban az értékelési keretrendszer alapvetően ex-ante elemzésre fókuszál, vagyis a várható kockázatok feltárásával segíti a döntéshozókat és a tervezőket. Ugyancsak erős negatív környezeti hatást okozhat a kerékpárút-hálózat és az úthálózat fejlesztése a zöldfelületek csökkenése, valamint - utóbbi esetben - az ingázók megnövekvő számával összefüggő, gyarapodó kibocsátás miatt.

Végül, érdemes megemlíteni a szárazhegyi munkahelyi övezet egyértelmüen pozitív összefüggését a gazdasági fenntarthatósággal: ez új munkahelyek létrehozásával hozzájárul a helyi gazdasági erőforrásokhoz, így közvetve növeli a népességmegtartó képességet (emberi erőforrások), és segíti a munka társadalmi körülményeinek fejlesztését (társadalmi erőforrások) is. Ugyanakkor a természeti erőforrások terén a burkolt felületek növekedését említhetjük közvetlen negatív hatásként. Az értékelési keretrendszert áttekintve érdemes kiemelni, hogy bár a vonatkozó kormányrendelet fenntarthatósági dimenziók mentén vezeti végig a 
2. táblázat: A kulcsprojektek fenntarthatósági szempontú elemzése Sustainability-oriented assessment of key urban development projects

\begin{tabular}{|c|c|c|c|c|}
\hline & $\begin{array}{l}\text { Emverı } \\
\text { erőforrások }\end{array}$ & $\begin{array}{l}\text { vazuasugı } \\
\text { erőforrások }\end{array}$ & $\begin{array}{l}\text { 1 ermeszeu } \\
\text { erőforrások }\end{array}$ & $\begin{array}{l}1 \text { ursuauırmı } \\
\text { erőforrások }\end{array}$ \\
\hline Középületek energetikai megújítása & + & $+/-$ & ++ & + \\
\hline $\begin{array}{l}\text { Megújuló energiaforrások használatának } \\
\text { elősegítése }\end{array}$ & ++ & + & + & NR \\
\hline Szakorvosi rendelő bővítés, korszerűsítés & ++ & $+/-$ & ++ & NR \\
\hline Multifunkciós sportcsarnok & ++ & ++ & -- & ++ \\
\hline Identitást erősítő projektek & ++ & + & ++ & ++ \\
\hline Biztonságos közterek & + & NR & NR & + \\
\hline Úthálózat fejlesztése & + & + & + és -- & NR \\
\hline Kerékpárhálózat fejlesztése & ++ & NR & +és - - & NR \\
\hline Alközpontok fejlesztése & ++ & ++ & NR & ++ \\
\hline $\begin{array}{l}\text { Munkahelyteremtés, szárazhegyi } \\
\text { munkahelyi övezet }\end{array}$ & ++ & ++ & +és - - & + \\
\hline
\end{tabular}

Forrás: saját szerkesztés

városfejlesztési szakembereket a tervezési folyamaton, az itt ismertetett kulcsprojektek közvetlen negatív hatásai mégis jellemzően a természeti erőforrásoknál jelentkeznek.

Tanulmányunk egyik legfontosabb célja a városfejlesztési projektek klímaadaptációs szempontú ex-ante értékelése. A korábban kiválasztott XVII. kerületi kulcsprojekteket a fóvárosi klímastratégia adaptációs célrendszere mentén is értékeltük annak érdekében, hogy a hosszú távú negatív hatásokkal járó beavatkozások még a tervezési időszak elején vagy azt megelőzően felszínre kerüljenek. Az értékelési rendszer a korábban bemutatott fenntarthatósági elemzéshez hasonlatos, az eredményeket a 3. táblázat foglalja össze.

A középületek energetikai felújításához alapvetően kibocsátáscsökkentési hatások kapcsolhatók, azonban néhány esetben közvetett, vagy akár közvetlen pozitív, alkalmazkodást elősegítő hatást is beazonosíthatunk. A felújított épületek esetében a hőveszteség drasztikusan csökkenthető, így a városi hőszigethatás is mérsékelhetővé válik. Az energetikai korszerüsítéssel párhuzamosan feltételezhetjük a vízhasználat hatékonyabbá válását, mely közvetett hatást jelent a vízgazdálkodás terén. A felújított és energetikai szempontból korszerüsített középületek hőhullámok esetén menedékként szolgálhatnak a legsérülékenyebb társadalmi csoportok számára, vagyis a humán egészségügy területén közvetlen pozitív hatást fejtenek ki. Végül, az épületek klímaváltozással (jellemzően viharokkal) szembeni sérülékenysége is csökkenthetö: ez ugyanakkor csak enyhe pozitív hatásként jelentkezik, mivel a vonatkozó adaptációs célkitűzés a turisztikai desztinációkra is utal, ami nem releváns tényező a kerületben. A megújuló energiaforrások 
használatának előtérbe helyezése a vízgazdálkodás terén enyhe tovagyürüző pozitív hatást okozhat, ha feltételezzük, hogy a tudatosabb lakossági energiafogyasztással együtt járhat a tudatos vízfelhasználás is.

A szakorvosi rendelő bővítése és korszerűsítése közvetett pozitív hatást fejt ki a városi hőszigethatás mérséklése és a vízgazdálkodás területén a középületeknél megismert logika alapján. A hőhullámokkal szembeni sérülékenység, a humán egészségügy területén azonban egyértelmü és közvetlen pozitív hatást feltételezünk. Az identitást erősítő projektek kapcsán alapvetően közvetett pozitív hatásokat azonosíthatunk: a kertvárosi identitás hozzájárul(hat) a zöldfelületek megőrzéséhez és a hőszigethatás mérsékléséhez. Az egészségügyi kockázat is csökkenthető, és a helyi értékekkel szembeni fokozott érzékenység részben ellensúlyozhatja a tájhasználat módosításából fakadó megnövekedett sérülékenységet.

A multifunkciós sportcsarnok létesítése - az előzőekben ismertetett kulcsprojektektől eltérően - inkább negatív potenciális hatásokkal jellemezhető a klímaadaptációs értékelési szempontok mentén. A zöldfelületek csökkenése várható a burkolt felületek megnövekedése mellett, és fokozott negatív hatás azonosítható be, amennyiben a beruházás a Néppark területét érintve valósulna meg. Az újabb beépítés miatt a városi hőszigethatás fokozódhat, a vízgazdálkodás terén pedig egy új nagyfogyasztó jelenik meg erős, közvetlen negatív hatást okozva. Pozitív hatásként jelenik meg ugyanakkor a tömegsportnak és a rekreációs célú felhasználásnak köszönhetően a lakosság általános egészségügyi állapotának javulása, mely természetszerűleg csökkenti a hőhullámokkal szembeni sérülékenységet is. A táj sérülékenysége azonban növekedhet, amennyiben a komplexum a Népparkot érintve, esetleg a Rákos-patak közelében épülne meg. Az épített környezet sérülékenységére jótékony hatással lehet az új sportcsarnok, mivel ebben az esetben a kerület épületállományának átlagos minősége is javuló tendenciát mutathat.

Az út- és kerékpárút-hálózat fejlesztése kapcsán lényegében hasonló klímaadaptációs hatásokat azonosíthatunk, így ezeket nem ismételjük meg. Mivel mindkét esetben új burkolt felületekkel is számolhatunk a meglévő úthálózat felújítása mellett, a zöldfelületek csökkenése, valamint a hőszigethatás növekedése prognosztizálható. Mivel a beruházások - a használattal összefüggésben - eltérő nagyságrendben valósulnak meg, a kerékpárutak esetében egy fokozattal enyhébb negatív hatást jeleztünk. A kerékpárút-hálózat bővítésével potenciálisan csökkenhet a gépjárművet használók száma a kerékpáros közlekedés javára, vagyis a hőszigetjelenség egyik legfontosabb hajtóereje, a gépjárművek által kibocsátott hő mennyisége mérséklődhet. A közúthálózat bővítése a lefolyási felületek növelésével halmozottan negatív hatással jár villámárvízi elöntések idején, azonban enyhe pozitív hatást is feltételezhetünk a megfelelően méretezett csapadékvíz-elvezető rendszer kapcsolódó kiépítésével. Az emberi egészségre a korábban említett hőszigethatás növekedése negatív következményekkel jár, azonban a megfelelő minőségű utakon a mentők és tűzoltók vonulása gyorsabbá válhat. A 
kerékpárutak tekintetében a rekreációs célú kerékpárhasználat javíthat a lakosság általános egészségi állapotán, mely hozzájárul a hőhullámokkal szembeni sérülékenység csökkenéséhez. A táji elemek sérülékenysége a közúthálózat bővítése során jelent potenciális konfliktusforrást.

A kerületi alközpontok fejlesztésével kapcsolatban részletek nem ismertek az integrált településfejlesztési stratégia alapján, ezért a megvalósítástól függ a zöldfelületek, a városi hősziget és az ezekkel összefüggő emberi egészség területén bekövetkező hatások iránya és nagysága. A középületek korszerüsítése ésszerübb és takarékosabb vízhasználathoz vezethet, valamint az épített környezet általános sérülékenysége is csökkenthetővé válik. A villámárvízi elöntésekkel összefüggő hatások azonban súlyosbodhatnak a kiterjedt burkolt felületek következményeként. Végül, a szárazhegyi munkahelyi övezet fejlesztésével összefüg-

3. táblázat: A kulcsprojektek klímaadaptációs szempontú értékelése Adaptation-oriented assessment of key urban development projects

\begin{tabular}{|c|c|c|c|c|c|c|c|}
\hline & Zöldfelïlet & $\begin{array}{c}\text { Városi } \\
\text { hösziget }\end{array}$ & $\begin{array}{c}\text { Viz- } \\
\text { gazdálkodás }\end{array}$ & $\begin{array}{c}\text { Arvizvédelmi } \\
\text { rendszer }\end{array}$ & Egészség & $\begin{array}{l}\text { Táj sérülé- } \\
\text { kenysége }\end{array}$ & $\begin{array}{r}\text { Epitett körny. } \\
\text { sérülékenység. }\end{array}$ \\
\hline $\begin{array}{l}\text { Középületek } \\
\text { energetikai } \\
\text { megúííása }\end{array}$ & NR & + & + & NR & ++ & NR & + \\
\hline $\begin{array}{l}\text { Megújuló } \\
\text { energiaforrások } \\
\text { használatának } \\
\text { elősegítése }\end{array}$ & NR & NR & + & NR & NR & - & NR \\
\hline $\begin{array}{l}\text { Szakorvosi } \\
\text { rendelő bővítés, } \\
\text { korszerűsítés }\end{array}$ & NR & + & + & NR & ++ & NR & NR \\
\hline $\begin{array}{l}\text { Multifunkciós } \\
\text { sportcsarnok }\end{array}$ & - & - & -- & NR & ++ & - & + \\
\hline $\begin{array}{l}\text { Identitást erő- } \\
\text { sítő projektek }\end{array}$ & + & + & NR & NR & + & + & + \\
\hline $\begin{array}{l}\text { Biztonságos } \\
\text { közterek }\end{array}$ & NR & NR & NR & NR & NR & NR & NR \\
\hline $\begin{array}{l}\text { Úthálózat } \\
\text { fejlesztése }\end{array}$ & -- & -- & - & +és-- & +és- & - & NR \\
\hline $\begin{array}{l}\text { Kerékpárhálózat } \\
\text { fejlesztése }\end{array}$ & - & +és- & - & NR & +és- & NR & NR \\
\hline $\begin{array}{l}\text { Alközpontok } \\
\text { fejlesztése }\end{array}$ & $+/-$ & $+1-$ & + & - & $+1-$ & NR & + \\
\hline $\begin{array}{l}\text { Munkahelyte- } \\
\text { remtés, száraz- } \\
\text { hegyi munkahe- } \\
\text { lyi övezet }\end{array}$ & - & -- & - & - & - & -- & NR \\
\hline
\end{tabular}

Forrás: saját szerkesztés 
gésben klímaadaptációs szempontból csak negatív hatásokat lehetett feltételezni. Ezek kiterjednek a burkolt felületek és a beépített területek növekedéséből következő zöldfelületi és hőszigethatással kapcsolatos anomáliákra, a csapadék hirtelen lefolyására, illetve az egészségügyi és táji sérülékenység növekedésére.

A bemutatott fenntarthatósági és klímaadaptációs értékelés mellett külön hangsúlyt kell, hogy kapjon a városfejlesztési beavatkozások potenciális hosszú távú negatív és pozitív beágyazódási lehetőségeinek feltárása. Az ún. lock-in elemzés jelenleg még gyerekcipőben jár a városfejlesztési gyakorlatban, habár annak elmélete és a kapcsolódó hatásértékelési mátrix nem sokban tér el a korábban bemutatottaktól. A 4. táblázatban a potenciális beágyazódásokat és kényszerpályákat - Ürge-Vorsatz és szerzőtársai (2018) ajánlásait követve - infrastrukturális, intézményi és viselkedési dimenziókban különböztettük meg.

A középületek energetikai felújítása során a kivitelezés minősége alapvetően befolyásolja az infrastrukturális kényszerpályák megjelenését, így a gyenge minőségű szigetelés, nyílászárócsere vagy éppen az elégtelen épületgépészeti megoldások hosszú távon gátolhatják az ÜHG-kibocsátás csökkentését. Viselkedési oldalról fennáll a veszélye a korábban alkalmazott gyakorlatok (pl. ablakok folyamatos nyitása, szellőző rendszerek nem megfelelő használata) folytatásából fakadó enyhe negatív berögzüléseknek. A megújuló energiaforrások használatát a meglévő infrastruktúra kapacitásai korlátozhatják, melyet intézményi oldalról a nem megfelelő és elegendő ösztönzők súlyosbíthatnak. A szakorvosi rendelő bővítése és felújítása a középületek energetikai megújításához hasonló infrastrukturális kényszerpályákat okozhat, azonban intézményi oldalról érdemes megemlíteni, hogy maga az infrastrukturális beruházás nem változtat az alulfinanszírozott és struktúrájában elavult rendszer müködésén. Ez utóbbi természetesen túlmutat a klímaadaptációs kihívásokon: ez a szemlélet a lock-in elemzés egyik legnagyobb előnye, vagyis megjelennek benne azok az ágazatspecifikus szempontok is, melyek egy fenntarthatósági elemzésben nem biztos, hogy helyet kapnának.

A multifunkciós sportcsarnok építése több évtizedre meghatározza a zöldinfrastruktúra-fejlesztési lehetőségeket a közelben, illetve intézményi oldalon hosszú távon jelentkező költségvonzatot eredményez, ugyanakkor a mozgáskultúra előtérbe helyezésével a viselkedési normák pozitív irányba változhatnak. Az identitást erősítő projektek jellegüknél fogva a viselkedési lock-in folyamatok területét érintik, melyen sokat javíthatnak megfelelő kommunikációval, azonban a korábban kialakult viselkedési berögződés - mely szerint a kerületben nincs szórakozási lehetőség - jelentősen gátolhatja a projektek sikerességét. A biztonságos közterek kialakításához hosszú távra telepített térfigyelő rendszer szükséges, melyet viselkedési oldalról esetleg bizalmatlanság, a megfigyeltség érzete ronthat a természetszerüleg megnövekedett biztonságérzet mellett. A köz- és kerékpárúthálózat fejlesztése alapvetően meghatározza az infrastrukturális állapotokat, melyek jellegüknél fogva évtizedekre is állandósulhatnak. Intézményi oldalról a külső forrásokra való túlzott támaszkodás a városfejlesztés belső forrásainak 
csökkenését idézheti elő. A kerékpárutak fejlesztése esetén az integrált szemlélet hiánya a felújítások duplikálását, hatékonyságuk csökkenését eredményezheti. A közúthálózat kiterjedt bővítése emellett gépjármühasználatra ösztönöz, ugyanakkor a kerékpárút-hálózat kiterjesztése ezzel ellentétes hatást válthat ki a nem motorizált közlekedési eszközök előtérbe helyezésével.

Az alközpontok fejlesztése a meglévő épületek korszerüsítése, felújítása révén hosszú időre meghatározhatja a pozitív összképet infrastrukturális oldalról, azonban a közteresítés és az alközpontok nem megfelelö közösségi közlekedési összeköttetése negatív kényszerpályákra sodorhatja a beavatkozást. Intézményi oldalról a finanszírozás kérdésében számíthatunk negatív hosszú távú hatásokkal, míg a viselkedési szempontokat figyelembe véve az eddig nem használt alközpontok azok élhetőségét, gazdasági megtérülését veszélyeztetik. A szárazhegyi munkahelyi övezet kialakítása a többi infrastrukturális beruházáshoz hasonló negatív hatásokkal járhat, ugyanakkor a kerületbe települő munkahelyek hosszú távon is biztosíthatják a megfelelő foglalkoztatottsági szintet és a kapcsolódó ellátásokat. Intézményi kényszerpályáról beszélhetünk a top-down tervezési módszer túlzott előtérbe kerülésekor, mely berögzülése esetén a későbbi városfejlesztési folyamatok hatékonyságát csökkentheti.

4. táblázat: A városfejlesztési kulcsprojektek lock-in alapú értékelése Lock-in analysis of key urban development projects Infrastruktúra lock-in Intézményi lock-in Viselkedési lock-in

\begin{tabular}{lccc}
\hline Középületek energetikai megújítása & - & $\mathrm{NR}$ & - \\
$\begin{array}{l}\text { Megújuló energiaforrások } \\
\text { használatának elősegítése }\end{array}$ & - & -- & - \\
$\begin{array}{l}\text { Szakorvosi rendelő bővítés, } \\
\text { korszerűsítés }\end{array}$ & - & -- & $\mathrm{NR}$ \\
Multifunkciós sportcsarnok & - & & + \\
$\begin{array}{l}\text { Identitást erősítő projektek } \\
\text { Biztonságos közterek }\end{array}$ & $\mathrm{NR}$ & $\mathrm{NR}$ & ++ és - \\
Úthálózat fejlesztése & + / & $\mathrm{NR}$ & + / - \\
Kerékpárhálózat fejlesztése & -- & - & -- \\
Alközpontok fejlesztése & - & -- & + \\
$\begin{array}{l}\text { Munkahelyteremtés, szárazhegyi } \\
\text { munkahelyi övezet }\end{array}$ & $+/-$ & -- & - \\
\hline
\end{tabular}




\section{Következtetések és összefoglalás}

Tanulmányunk célja egy olyan komplex értékelési keretrendszer bemutatása volt, mely ex-ante módon képes megítélni kulcsfontosságú városfejlesztési beruházásokat fenntarthatósági, klímaadaptációs és lock-in szempontból. Esettanulmányként - alapul véve a kerület heterogén társadalmi, gazdasági és környezeti viszonyait, illetve a helyi klímastratégia hiányát - a Budapest XVII. kerületének integrált településfejlesztési stratégiájában szereplő kulcsprojekteket választottuk. A fenntarthatósági alapú elemzésből kitűnik, hogy e projektek döntően pozitív hatást gyakorolnak az emberi és gazdasági erőforrásokra, ugyanakkor egyes tervezett beruházások a természeti erőforrásokat negatívan befolyásolják. Mivel az eredmények értelmezésénél az ún. „erős fenntarthatóság” fogalomrendszerét vettük alapul, a kulcsprojektek tervezésénél és kivitelezésénél javasolt a természeti erőforrások határozottabb figyelembevétele, különös tekintettel a hosszú távon is meghatározó tovagyürüző hatásokra.

A klímaadaptációs szempontok meghatározása során a 2018-ban elfogadott fővárosi klímastratégia alkalmazkodási célrendszerét vettük alapul. Az értékelési mátrix megmutatta, hogy a fenntarthatósági értékelésnél jóval több esetben feltételezhetünk közvetlen vagy közvetett negatív hatást, főleg az infrastrukturális beruházások esetében. Ezen kulcsprojektek egyszerre több adaptációs területet is negatívan érinthetnek, éppen ezért a már korábban említett tervezési és végrehajtási, illetve üzemeltetési szakaszban kiemelten fontos az adaptációs szempontok figyelembevétele és érvényesítése. A klímaadaptációs értékelés a szakirodalmi áttekintésben azonosított fenntarthatóság-alkalmazkodás összefüggéseknek megfelelően olyan területre irányította a figyelmet, mely a fenntarthatósági elemzésben rejtve maradt. Feltételezve, hogy a klímaváltozáshoz alkalmazkodás a városi fenntarthatóság fogalomrendszerén belül, annak egy speciális horizontális elemeként értelmezendő, a negatív hatások kiküszöbölése vagy csökkentése hozzájárul az ún. „erős fenntarthatóság” elvrendszerének érvényre juttatásához.

A tanulmány harmadik értékelési szempontja a lock-in elemzés volt: ennek keretében infrastrukturális, intézményi és viselkedési kényszerpályák beazonosításával sikerült azokat a kulcsprojekteket megkülönböztetni, melyek jelentős hosszú távú negatív hatással bírnak.

Kiemelendő az alkalmazott módszertan univerzalitása, mely azonban az eredményeket tekintve nagyban függ a helyi és térségi viszonyoktól, fejlesztési céloktól és a figyelembe vett alkalmazkodási szempontoktól. Az alkalmazott három értékelési keretrendszer bármelyik hazai település fejlesztési stratégiáinak ex-ante kvalitatív elemzéséhez felhasználható, segítségükkel pedig olyan fenntarthatósági szempontok is figyelembe vehetők, melyek egy klasszikus fenntarthatósági hatáselemzés során esetleg rejtve maradnának. Az elemzések eredményei olyan inputot szolgáltatnak a városfejlesztés ex-ante szakaszában a tervezők és döntéshozók számára, melyeket eddig nem, vagy csak érintőlegesen vettek számba, holott lát- 
hattuk, hogy a klímaadaptáció a fenntarthatóság egy aspektusaként értelmezve igenis meghatározó erővel bír. Itt érdemes megjegyezni, hogy az értékelések során azonosított negatív hatások megléte nem jelenti a teljes beruházás, illetve kulcsprojekt eltörlését vagy jelentőségének csökkenését, azonban felhívja a döntéshozók és tervezők figyelmét olyan potenciális hatásokra, melyek komolyan veszélyeztetik a hosszú távon is értelmezendő fenntarthatóság érvényre juttatását.

A módszertan alkalmazhatóságának lényeges eleme, hogy a tervezés során, vagyis a városfejlesztési projektek szempontjából ex-ante szolgáltat olyan eredményeket, melyek a későbbi fejlesztési döntések meghozatalánál befolyásoló erővel bírnak. Az esettanulmány-jelleget szem előtt tartva, egy közgyülési határozattal már elfogadott integrált településfejlesztési stratégiát választottunk, ahol az utólagos hatáselemzés - különösen egyes projektek kivitelezése után - már csekély hozzáadott értékkel bír. További korlátozó tényező az elemzés kvalitatív jellege, amelyet későbbi kutatások során célszerű fokozatosan kvantitatívvá alakítani az objektív, statisztikai és városfejlesztési adatokon nyugvó elemzések érvényre juttatásával. Így a kapott eredmények módszertani szempontból szilárdabb lábakon állhatnak, egyben csökkenthetővé válik a szubjektív befolyásoló tényezők köre is. Összefoglalva elmondható, hogy a kidolgozott módszertan alkalmas a városfejlesztési projektek komplex értékelésére: így a fenntarthatóság olyan szempontjai is terítékre kerülhetnek a potenciális kényszerpályák mellett, melyek valódi hozzáadott értékkel bírnak a városfejlesztési szakemberek és döntéshozók számára.

\section{Irodalom}

Anderies, J. M., Folke, C., Walker, B., Ostrom, E. (2013): Aligning key concepts for global change policy: Robustness, resilience, and sustainability. Ecology and Society, 2., 8. https://doi.org/10.5751/ ES-05178-180208

Baji P. (2017): Okos városok és alrendszereik - Kihívások a jövő városkutatói számára? Tér és Társadalom, 1., 89-105. https://doi.org/10.17649/tet.31.1.2807

Baros Z. (2012): Települési környezeti minőség, fenntarthatóság és városmarketing - különös tekintettel a zajterhelésre és az önkormányzatok szerepére. Tér és Társadalom, 3., 48-68. https:// doi.org/10.17649/TET.26.3.2055

Battersby, J. (2017): MDGs to SDGs-new goals, same gaps: the continued absence of urban food security in the post-2015 global development agenda. African Geographical Review, 1., 115-129. https://doi.org/10.1080/19376812.2016.1208769

Bocchini, P., Frangopol, D. M., Ummenhofer, T., Zinke, T. (2014): Resilience and sustainability of civil infrastructure: Toward a unified approach. Journal of Infrastructure Systems, 2., 1-16. https:// doi.org/10.1061/(ASCE)IS.1943-555X.0000177

Bozza, A., Asprone, D., Manfredi, G. (2015): Developing an integrated framework to quantify resilience of urban systems against disasters. Natural Hazards, 3., 1729-1748. https://doi.org/10.1007/s11069015-1798-3

Buzási A., Szalmáné Csete M. (2018): Fenntartható fejlődés és klímaváltozás - globális összefüggések lokális értelmezése. Magyar Tudomány, 9., 1349-1358. https://doi.org/10.1556/2065.179.2018.9.8 
Carter, J. G., Cavan, G., Connelly, A., Guy, S., Handley, J., Kazmierczak, A. (2015): Climate change and the city: Building capacity for urban adaptation. Progress in Planning, 95, 1-66. https://doi.org/10.1016/ j.progress.2013.08.001

Champagne, C. L., Aktas, C. B. (2016): Assessing the Resilience of LEED Certified Green Buildings. Procedia Engineering, 145., 380-387. https://doi.org/10.1016/j.proeng.2016.04.095

Chelleri, L., Schuetze, T., Salvati, L. (2015): Integrating resilience with urban sustainability in neglected neighborhoods: Challenges and opportunities of transitioning to decentralized water management in Mexico City. Habitat International, 48., 122-130. https://doi.org/10.1016/ j.habitatint.2015.03.016

Chester, M. V, Sperling, J., Stokes, E., Allenby, B., Kockelman, K., Kennedy, C., Baker, L. A., Keirstead, J., Hendrickson, C. T. (2014): Positioning infrastructure and technologies for low-carbon urbanization. Earth's Future, 10., 533-547. https://doi.org/10.1002/2014EF000253

Cohen, M. (2017): A systematic review of urban sustainability assessment literature. Sustainability, 11., 1-16. https://doi.org/10.3390/su9112048

Csete, M., Buzási, A. (2016): Climate-oriented assessment of main street design and development in Budapest. Journal of Environmental Engineering and Landscape Management, 4., 258-268. https:// doi.org/10.3846/16486897.2016.1185431

Csiszár Cs., Csonka B., Földes D., Wirth E., Lovas T. (2019): Városi elektromos töltőállomások helyszínét kijelölő módszer. Közlekedéstudományi Szemle, 3., 5-18. https://doi.org/10.24228/KTSZ. 2019.3.1

Egedy T. (2017): Városfejlesztési paradigmák az új évezredben - a kreatív város és az okos város. Földrajzi Közlemények, 3., 254-262.

Engle, N. L., de Bremond, A., Malone, E. L., Moss, R. H. (2014): Towards a resilience indicator framework for making climate-change adaptation decisions. Mitigation and Adaptation Strategies for Global Change, 8., 1295-1312. https://doi.org/10.1007/s11027-013-9475-x

Enyedi Gy. (2011): A városnövekedés szakaszai - újragondolva. Tér és Társadalom, 1., 5-19. https:// doi.org/10.17649/TET.25.1.1770

Farkas J. Zs., Rakonczai J., Hoyk E. (2015): Környezeti, gazdasági és társadalmi éghajlati sérülékenység: esettanulmány a Dél-Alföldről. Tér és Társadalom, 1., 149-174. https://doi.org/10.17649/ TET.29.1.2675

Fleischer T. (2019): Városi mobilitás, közjavak, fenntarthatóság. Közgazdasági Szemle, 10., 1056-1072. https://doi.org/10.18414/KSZ.2019.10.1056

Fodor L., Barta A., Fónai M., Bányai O. (2016): Települési környezetvédelem Magyarországon: Egy kutatás előfeltevései. Tér és Társadalom, 3., 19-39. https://doi.org/10.17649/TET.30.3.2763

Folke, C. (2016): Resilience (Republished). Ecology and Society, 4., 44. https://doi.org/10.5751/ES09088-210444

Folke, C., Carpenter, S., Elmqvist, T., Gunderson, L., Holling, C. S., Walker, B. (2002): Resilience and sustainable development: Building adaptive capacity in a world of transformations. Ambio, 5., 437-440. https://doi.org/10.1579/0044-7447-31.5.437

Friedland, C. J., Gall, M. (2012): True cost of hurricanes: Case for a comprehensive understanding of multihazard building damage. Leadership and Management in Engineering, 3., 134-146.

https://doi.org/10.1061/(ASCE)LM.1943-5630.0000178

González Medina, M., Fedeli, V. (2015): Exploring European urban policy: Towards an EU-national urban agenda? Gestión Y Análisis De Políticas Públicas, 14., 8-22. https://doi.org/10.24965/ gapp.v0i14.10287

Kántor N., Gulyás Á., Szkordilisz F., Pásztor P., Kovács A., Kiss M. (2017): Nature4Cities: A természetalapú megoldások (nature-based solutions) alkalmazási lehetőségei a várostervezésben. In: Blanka V., Ladányi Zs. (szerk.): Interdiszciplináris tájkutatás a XXI. században. A VII. Magyar Tájökológiai Konferencia Tanulmányai. Szegedi Tudományegyetem Földrajzi és Földtudományi Intézet, Szeged, 295-304.

Kis, A., Pongrácz, R., Bartholy, J. (2017): Multi-model analysis of regional dry and wet conditions for the Carpathian Region. International Journal of Climatology, 13., 4543-4560. https://doi.org/ 10.1002/joc.5104 
Kohán Z., Rideg A., Péti M., Dobozi E., Györe Á. (2011): A klímaváltozás városi és területi sajátosságai - európai körkép. Területi Statisztika, 4., 405-428.

Központi Statisztikai Hivatal (2020): Tájékoztatási adatbázis, területi statisztika (Letöltés: 2020.06.14.)

Kun L. (2016): Városfejlesztés és okos városok a mutatószámok tükrében. Információs Társadalom, 3., 157-164. http://dx.doi.org/10.22503/inftars.XVI.2016.3.8

Lados M., Tóth M. L. (2019): Autonóm járművek az okos városokban. Tér, Gazdaság, Ember, 1., 159-173.

Lew, A. A., Ng, P. T., Ni, C., Wu, T. (2016): Community Sustainable and Resilience: Similarities, Differencies and Indicators. Tourism Geographies, 1., 18-27. https://doi.org/10.1080/14616688.2015.1122664

Lizarralde, G., Chmutina, K., Bosher, L., Dainty, A. (2015): Sustainability and resilience in the built environment: The challenges of establishing a turquoise agenda in the UK. Sustainable Cities and Society, 15., 96-104. https://doi.org/10.1016/j.scs.2014.12.004

Málovics Gy., Bajmócy Z. (2009): A fenntarthatóság közgazdaságtani értelmezései. Közgazdasági Szemle, 5., 464-483.

Marjaba, G. E., Chidiac, S. E. (2016): Sustainability and resiliency metrics for buildings - Critical review. Building and Environment, 101., 116-125. https://doi.org/10.1016/j.buildenv.2016.03.002

Phillips, R., Troup, L., Fannon, D., Eckelman, M. J. (2017): Do resilient and sustainable design strategies conflict in commercial buildings? A critical analysis of existing resilient building frameworks and their sustainability implications. Energy and Buildings, 146., 295-311. https://doi.org/10.1016/j.enbuild. 2017.04.009

Pongrácz, R., Bartholy, J., Kis, A. (2014): Estimation of future precipitation conditions for Hungary with special focus on dry periods. Időjárás, 4., 305-321.

Romero-Lankao, P., Bulkeley, H., Pelling, M., Burch, S., Gordon, D. J., Gupta, J., Johnson, C., Kurian, P., Lecavalier, E., Simon, D., Tozer, L., Ziervogel, G., Munshi, D. (2018): Urban Transformative Potential in a Changing Climate. Nature Climate Change, 9., 754-756. https://doi.org/10.1038/ s41558-018-0264-0

Roostaie, S., Nawari, N., Kibert, C. J. (2019): Sustainability and resilience: A review of definitions, relationships, and their integration into a combined building assessment framework. Building and Environment, 154., 132-144. https://doi.org/10.1016/j.buildenv.2019.02.042

Szabó, B., Vincze, E., Czúcz, B. (2016): Flowering phenological changes in relation to climate change in Hungary. International Journal of Biometeorology, 9., 1347-1356. https://doi.org/10.1007/ s00484-015-1128-1

Szlávik J. (2014): Lépések a fenntartható gazdálkodás irányába: Gondolatok Láng István és Kerekes Sándor Megalakult a Túlélés Szellemi Kör című vitairatához. Magyar Tudomány, 1., 99-108. http://www.matud.iif.hu/2014/01/15.htm (Letöltve: 2020.06.13.)

Torma, Cs. Zs. (2019): Detailed validation of EURO-CORDEX and Med-CORDEX regional climate model ensembles over the Carpathian Region. Idojjárás, 2., 217-240. https://doi.org/10.28974/ idojaras.2019.2.6

UN (2019): World Population Prospects 2019, Volume I: Comprehensive Tables (ST/ESA/SER.A/426).

Ürge-Vorsatz, D., Rosenzweig, C., Dawson, R. J., Sanchez Rodriguez, R., Bai, X., Salisu Barau, A., Seto, K. C., Dhakal, S. (2018): Locking in positive climate responses in cities Adaptationmitigation interdependencies. Nature Climate Change, 3., 174-177. https://doi.org/10.1038/ s41558-018-0100-6

Uzzoli A., Bán A. (2018): A hazai települési önkormányzatok adaptációs lehetőségei a klímaváltozás egészséghatásainak kezelésében. In: Fata I., Gajzágó É. J., Schuchmann J. (szerk.): Tudományos Mozaik 14. Tomori Pál Főiskola, Budapest, 212-219.

Xu, L., Marinova, D., Guo, X. (2015): Resilience thinking: a renewed system approach for sustainability science. Sustainability Science, 1., 123-138. https://doi.org/10.1007/s11625-014-0274-4

Zefreh, M. M., Török Á. (2020): Distribution of traffic speed in different traffic conditions: an empirical study in Budapest. Transport (Vilnius), 1., 68-86. https://doi.org/10.3846/transport.2019.11725 


\section{Dokumentumok}

Budapest Főváros XVII, kerület Rákosmente Településfejlesztési Koncepciójának és Integrált Településfejlesztési Stratégiájának Megalapozó Vizsgálata 2015. http://www.rakosmente.hu/Files/ megalapozo_vizsgalat_1_kotet.pdf (Letöltés: 2020.06.14.)

Budapest Klímastratégiája 2018. https://budapest.hu/Documents/klimastrategia/Bp_Klimastrategi\%C3\%A1ja_vegleges_KGY\%20elfogadott.pdf (Letöltés: 2020.06.14.)

Nemzeti Fenntartható Fejlődési Keretstratégia (2013). https://www.nfft.hu/documents1238941/4101589/ Nemzeti+Fenntarthat\%C3\%B3+Fejl\%C5\%91d\%C3\%A9si+Keretstrat\%C3\%A9gia.pdf/4ee5e5a1-4bbc4433-8245-dd2f52a4e667?t=1580132846319 (Letöltés: 2020.09.16.)

Országos Területfejlesztési és Területrendezési Információs Rendszer (2020): Integrált Településfejlesztési Stratégia tervezését támogató alkalmazás (Letöltés: 2020.06.14.)

Rákosmente Integrált Településfejlesztési Stratégiája 2015-2020 (2015). http://www.rakosmente.hu/ Libraries/szab\%C3\%A1lyoz\%C3\%A1si_tervek_elfog_el\%C5\%91tt/Hat_jav_2_sz_mell\%C3\%A9kete_ITS.sflb.ashx (Letöltés: 2020.06.14.)

Rákosmente Településfejlesztési Koncepciója 2015-2030 (2015). http://www.rakosmente.hu/Libraries/szab\%C3\%A1lyoz\%C3\%A1si_tervek_elfog_el\%C5\%91tt/325_2015_IX_24_Kt_hat_1_sz mell\%C3\% A9klete-RaKOSMENTE_TK.sflb.ashx (Letöltés: 2020.06.14.) 